\title{
Quality of Life of Pregnant Women Living with HIV/AIDS
}

\section{Qualidade de vida de gestantes vivendo com HIV/Aids}

\author{
Marysabel Pinto Telis Silveira ${ }^{1}$ Mariângela Freitas Silveira ${ }^{2}$ Cristina Heloisa Müller ${ }^{3}$
}

${ }^{1}$ Department of Physiology and Pharmacology, Instituto de Biologia, Universidade Federal de Pelotas, Pelotas, RS, Brazil

Address for correspondence Marysabel Pinto Telis Silveira, PhD,

2 Maternal and Infant Health Department, Faculdade de Medicina, Centro de Epidemiologia UFPel, Marechal Deodoro, 1160, Centro, 96020Universidade Federal de Pelotas, Pelotas, RS, Brazil

${ }^{3}$ Faculdade de Farmácia, Universidade Federal de Pelotas, Pelotas, RS, Brazil 220, Pelotas, RS, Brazil (e-mail: marysabelfarmacologia@yahoo.com.br).

Rev Bras Ginecol Obstet 2016;38:246-252.

\begin{abstract}
Keywords

- pregnant women

- AIDS serodiagnosis

- quality of life

- questionnaires

- prenatal care
\end{abstract}

Objective to evaluate the quality of life of HIV positive (HIV+) pregnant women using the HIV/AIDS Target Quality of Life (HAT-QoL) instrument.

Methods cross-sectional study, conducted between May 2014 and November 2015, with HIV + pregnant women selected by convenience sampling. Sociodemographic and behavioral data were collected through interviews, and the HAT-QoL questionnaire was applied. Clinical and laboratorial data were collected from medical records.

Results twenty-seven pregnant women participated in the study. Their mean age was 27 years (standard deviation - SD: 7.3). The majority (59\%) had up to 8 years of education, $52 \%$ identified themselves as white, $56 \%$ were unemployed, and $59 \%$ had a household income higher than the minimum wage. The mean infection time by the virus was 68.4 months (5.7 years). The majority (74\%) were contaminated with HIV through sexual intercourse, and $67 \%$ declared not having a HIV + relative. Regarding the use of condoms, $41 \%$ reported using them sporadically, and the same number did not have proper knowledge about them. Only 23 patients (85\%) reported having been prescribed antiretrovirals. Fourteen (64\%) had a CD4 count higher than 500 cells $/ \mathrm{mm}^{3}$, and 13 pregnant women (59\%) had an undetectable viral load. The scores from the quality of life questionnaire dimensions that were more affected are: infection "disclosure concerns" (mean: 39.8; SD: 27.1), followed by "financial concerns" (mean: 49.1; SD: 36), and "HIV acceptance" (mean: 49.1; SD: 35.8). The dimension with the best score was "medication concerns" (mean: 80.8; SD: 26.5).

Conclusion quality of life has been increasingly used as a clinical outcome evaluation parameter. The results of this study contribute to the establishment of interventions based on the needs of HIV+ pregnant women. received

November 27, 2015

accepted

April 4, 2016

published online

May 17, 2016
DOI http://dx.doi.org/

$10.1055 / \mathrm{s}-0036-1584164$. ISSN 0100-7203.
Copyright $(2016$ by Thieme Publicações License terms Ltda, Rio de Janeiro, Brazil 


\section{Resumo}

\section{Palavras-chave \\ - gestantes \\ - sorodiagnóstico da AIDS \\ - qualidade de vida \\ - questionários \\ - cuidado pré-natal}

Objetivo Avaliar a qualidade de vida de gestantes com sorologia positiva para o HIV através do instrumento Target Quality of Life (HAT-QoL).

Métodos Estudo transversal, realizado de maio de 2014 a novembro de 2015, em gestantes HIV + , sendo a amostra de conveniência. Através de entrevista foram coletados dados sociodemográficos, comportamentais e aplicado o questionário HATQoL. Dados clínicos e laboratoriais foram aferidos dos prontuários.

Resultados Participaram 27 gestantes. A idade média foi de 27 anos (dp:7,3). A maioria (59\%) tem até oito anos de estudo, 52\% se declararam brancas, 56\% não estavam trabalhando e $59 \%$ tinham renda familiar superior a um salário mínimo. 0 tempo médio de infecção pelo vírus foi de 68,4 meses (5,7 anos). A maioria (74\%) foi contaminada pelo HIV através da relação sexual e (67\%) refere não ter familiar HIV + . Em relação ao uso do preservativo, $41 \%$ declararam usar às vezes e a mesma proporção não tinha conhecimento adequado sobre o mesmo. Apenas 23 pacientes (85\%) relataram prescrição de antirretrovirais. Apresentaram CD4 superior a 500 células/ mm3 14 (64\%) e carga viral indetectável 13 (59\%) gestantes. Os escores dos domínios do questionário de qualidade de vida mais comprometidos foram "Preocupação com sigilo sobre a infecção" (média: 39,8; dp: 27,1) seguido de "Preocupações financeiras" (média: 49,1; dp: 36) e "Aceitação do HIV"(média: 49,1; dp: 35,8). O domínio com melhor escore foi "Preocupação com a medicação" (média: 80,8; dp: 26,5).

Conclusão A qualidade de vida vem sendo utilizada cada vez mais como avaliação de desfecho clínico, os resultados deste estudo contribuem para estabelecimento de intervenções baseadas nas necessidades das gestantes que vivem com HIV.

\section{Introduction}

Over the past five years, Brazil has registered an annual average of 40.6 thousand cases of AIDS. In pregnant women, from the year 2000 until June 2015, 92,210 notifications of pregnant women with positive HIV serology occurred. ${ }^{1}$

Before the 1990s, scarce therapeutic solutions were available to mitigate the effects of the human immunodeficiency virus (HIV). ${ }^{2}$ Currently, however, the appearance of superior and more potent medications offers a better quality of life and increases the life expectancy of these patients ${ }^{3}$

In clinical practice, for individuals with positive HIV/AIDS serology, parameters such as CD4 count, viral load, and opportunistic diseases are used to evaluate the disease's progression, to indicate the initiation of therapy, and to verify the efficacy of the antiretrovirals. However, the clinical data alone is often not enough to understand the complexity of treatment outcomes and therapeutic interventions. ${ }^{4}$

Quality of life measurement is increasingly being used to complement the clinical or biological management of a disease, because it provides data that helps evaluate the quality of patient care, as well as the need for more health care and the efficacy of the interventions. Thus, it improves the patient's feelings and treatment satisfaction, unlike traditional care, which is focused on the evolution of the disease. ${ }^{5}$

In HIV positive $(\mathrm{HIV}+)$ individuals, quality of life measurement is essential, considering the fact that AIDS is a stigmatizing and still incurable disease, which leads to numerous biopsychosocial consequences that influence their quality of life. ${ }^{6}$ In pregnant women, there is also the need for special attention due to the risk of HIV vertical transmission (VT) and the fact that the fetus' wellbeing is also in jeopardy. ${ }^{7}$

Prophylaxis against vertical HIV transmission is supported by the recommendations of the Ministry of Health, ${ }^{8}$ which guides assistance to pregnant women and parturient women with positive HIV/AIDS serology, recommending measures to increase access to anti-HIV testing during prenatal routines, and measures to perform rapid tests at obstetric and prenatal centers. Late diagnosis of an HIV infection during pregnancy, low adherence to the technical recommendations by healthcare providers, and the low quality of assistance available, especially in regions with lower coverage and less access to healthcare services, are the main factors that interfere with the reduction of the national prevalence of HIV vertical transmission. It is necessary to understand the critical factors that determine the success of the interventions, and to expand these interventions to that population. ${ }^{9}$

Many international studies have evaluated the quality of life of patients with positive HIV serology. However, the majority of the instruments were developed in North American populations, with little existing knowledge regarding the quality of life of these patients in South America, where the incidence is still concerning. ${ }^{10}$ The HIV/Aids Target Quality of Life (HAT-QoL) was the first instrument developed using qualitative methods. ${ }^{11}$ Its dimensions were created entirely considering the perspective of individuals that live with HIV, and were based on what they considered relevant and important. ${ }^{12}$

It is noted that there are few studies that use the HAT-QoL instrument in Brazil. Such studies are even scarcer in 
pregnant women, and this is what stimulated the creation of this study, since, in this period of life, deep biological, psychological, inter-relational and sociocultural changes take place that impact the physical and mental health of these patients. Therefore, the goal of this study is to evaluate the quality of life of pregnant women with positive HIV serology, using the HAT-QoL instrument.

\section{Methods}

This is a cross-sectional, descriptive study that includes pregnant women with positive HIV serology, patients of the HIV/AIDS Specialized Assistance Clinic at the Federal University of Pelotas Medical School (UFPel). The pregnant women were participants of the HIV/AIDS Patient Interdisciplinary Care Program, addressed in the Proext-MEC 2014 public notice.

The sample was selected by convenience, and every pregnant woman that came to the clinic was invited, regardless of their gestational period, from May 2014 to- November 2015. Only pregnant women that agreed and signed the Informed Consent Form participated. The project was approved by the Research Ethics Committee at the university Universidade Federal de Pelotas under case number 508,798.

An interview was conducted in a private room, to guarantee privacy. The sociodemographic variables (age, education level, race, housing status, household income) were collected through a semi-structured questionnaire, previously used for other studies. $^{13,14}$ Other information obtained included: form of contamination, years of contamination, people who live with them that are contaminated with the virus, prescribed medications, drug allergies, smoking status, frequency of condom use, and knowledge about proper condom use. Information extracted from the medical records included marital status, partner's status, and all the CD4 count and viral load results for each pregnant woman that participated in the study.

The pregnant women's quality of life was assessed through an interview, using the Targeted Quality of Life $(\text { HAT-QoL) })^{15}$ instrument, which is specific for evaluating the quality of life of patients with positive HIV serology. This instrument consists of 34 items distributed in nine dimensions: overall function, satisfaction with life, health concerns, financial concerns, medication concerns, HIV acceptance, disclosure concerns, and provider trust (physician, nurse, or any other healthcare professional taking care of the patient). For the answers, a Likert-type scale was used with five options: "all the time," "most of the time," "part of the time," "seldom" and "never," with the points being calculated by the dimension scores and ranging from 0 to $100 .^{12}$

Data were double entered in an Excel spreadsheet to analyze inconsistencies, quality of life scores, and for descriptive analysis.

\section{Results}

Forty-five pregnant women were registered at the service during the time of the study. Fifteen (33\%) were not included at that time due to their irregular attendance at the service, and three $(7 \%)$ refused to participate. Our sample consisted of 27 (60\%) pregnant women. From these, 2 (7\%) were in the $1 \mathrm{st}$ trimester, 12 (44\%) in the 2nd trimester, and another 12 (44\%) in the 3rd trimester. One (4\%) did not follow up after the first prenatal consultation and, therefore, it was impossible to obtain her data.

The mean age was 27 years (SD: 7.3), ranging from 17 to 37 . The majority, 16 (59\%), had up to 8 years of education; 14 (52\%) declared themselves white; 15 (56\%) were unemployed; and 16 (59\%) had a household income superior to the minimum wage. All of them lived in a house or apartment, with relatives or partners. The sociodemographic characteristics of the sample are shown in - Table 1. Clinical and behavioral data are shown in - Table 2 .

The mean time since the infection by the virus was 68.4 months (5.7 years). Only one (4\%) participant contracted the virus through vertical transmission; 20 (74\%) were infected with HIV through sexual intercourse. The majority, 18 (67\%), reported not having HIV+ relatives; 22 (81\%) reported not having any kind of allergy; and 17 (63\%) were smokers or former smokers. Regarding the frequency of condom use, 11 (41\%) of them reported using it sometimes, and when questioned about their importance, only 11 (41\%) had proper knowledge of it. Twenty-three (85\%) reported having been prescribed antiretrovirals. Five pregnant women did not have CD4 count or viral load data documented in their medical records, three because they were at the beginning of the treatment, and the others because the test results were

Table 1 Sociodemographic characteristics of pregnant women with positive HIV serology $(n=27)$

\begin{tabular}{|c|c|c|}
\hline Variables & Frequency $n$ & $\%$ \\
\hline \multicolumn{3}{|l|}{ Age (years) } \\
\hline $17-26$ & 14 & 52 \\
\hline $27-37$ & 13 & 48 \\
\hline \multicolumn{3}{|l|}{ Education (years) } \\
\hline $0-8$ & 16 & 59 \\
\hline $9-11$ & 11 & 41 \\
\hline \multicolumn{3}{|l|}{ Ethnicity } \\
\hline White & 14 & 52 \\
\hline Non-white & 13 & 48 \\
\hline \multicolumn{3}{|l|}{${ }^{*}$ Household income } \\
\hline$\leq 1$ minimum wage & 11 & 41 \\
\hline$>1$ minimum wage & 16 & 59 \\
\hline \multicolumn{3}{|l|}{ Employment } \\
\hline Unemployed & 15 & 56 \\
\hline Worked as an employee & 7 & 26 \\
\hline $\begin{array}{l}\text { Worked in her own } \\
\text { business or odd jobs }\end{array}$ & 5 & 18 \\
\hline
\end{tabular}

Abbreviation: $n$, number.

*minimum wage value: $\mathrm{R} \$ 788,00$. 
Table 2 Clinical and behavioral data of pregnant women with positive HIV serology $(n=27)$

\begin{tabular}{|c|c|c|}
\hline Variables & $\mathbf{n}$ & $\%$ \\
\hline \multicolumn{3}{|l|}{ Form of contamination } \\
\hline Sexual intercourse & 20 & 74 \\
\hline Vertical transmission & 1 & 4 \\
\hline Unknown & 6 & 22 \\
\hline $\begin{array}{l}\text { Time of diagnosis in years. } \\
\text { Mean (SD) }\end{array}$ & $\begin{array}{l}5.7 \\
(5.2)\end{array}$ & - \\
\hline Does not have $\mathrm{HIV}+$ relative & 18 & 67 \\
\hline \multicolumn{3}{|l|}{ Marital status } \\
\hline With partner & 22 & 81 \\
\hline Without partner & 4 & 15 \\
\hline Not informed & 1 & 4 \\
\hline \multicolumn{3}{|l|}{ Partner status } \\
\hline $\mathrm{HIV}+$ & 7 & 26 \\
\hline HIV- & 14 & 52 \\
\hline Without partner & 4 & 15 \\
\hline Not informed & 2 & 7 \\
\hline $\begin{array}{l}\text { Reported receiving prescription } \\
\text { for antiretrovirals }\end{array}$ & 23 & 85 \\
\hline Does not have drug allergy & 22 & 81 \\
\hline Smoker or former smoker & 17 & 63 \\
\hline \multicolumn{3}{|l|}{ Condom use frequency } \\
\hline Always & 10 & 37 \\
\hline Sometimes & 11 & 41 \\
\hline Never & 6 & 22 \\
\hline Knowledge about the use of condoms* & 11 & 41 \\
\hline \multicolumn{3}{|l|}{ CD4 count (cells $\left./ \mathrm{mm}^{3}\right)^{* *}$} \\
\hline $50 \mathrm{~mm}<350$ & 7 & 32 \\
\hline 350 to 500 & 1 & 4 \\
\hline$>500$ & 14 & 64 \\
\hline \multicolumn{3}{|c|}{ Viral load (HIV-RNA lower than 50 copies $/ \mathrm{mL}$ ) ${ }^{* * *}$} \\
\hline Detectable & 9 & 48 \\
\hline Undetectable & 13 & 59 \\
\hline
\end{tabular}

Abbreviations: n, number; SD, standard deviation; HIV + , HIV-positive; HIV-, HIV-negative.

*the answer was considered correct when option 4 ("all of the above") was chosen for the following question: "In your opinion, a condom is used for what: (1) To avoid pregnancy, (2) To avoid sexually transmitted diseases, (3) To avoid HIV, (4) All of the above".

${ }^{* *} n=22$, five pregnant women did not have viral load and CD4 count tests. ${ }^{* * *}$ result closest to the labor and delivery period, prepartum and postpartum.

still not available. Among the 22 participants with laboratory results, $14(64 \%)$ had a CD4 count higher than 500 cells $/ \mathrm{mm}^{3}$, and 13 (59\%) had an undetectable viral load. From these results, it was possible to identify a favorable evolution of the viral load and CD4 count during the prenatal consultations in
9 (41\%) participants, because they had more than one test performed during this period.

It was not possible to obtain the vertical transmission rate of the newborns from the women in this study. However, the vertical transmission rate of pregnant women that use this service has remained under $2 \%$.

The antiretroviral regimen most used by the participants was the combination of protease inhibitors and nucleoside reverse transcriptase inhibitors. The majority 22 (81\%) used the association lamivudine + zidovudine + lopinavir/ritonavir. Four (15\%) patients changed the antiretroviral regimen when they started the prenatal follow up, and one (4\%) remained on her previous regimen, composed of the association of stavudine + didanosine + lopinavir/ritonavir. We were not able to obtain information regarding the medications used by one (4\%) pregnant woman, because she left the prenatal service right after the first consultation.

- Table 3 shows the scores of each HAT-QoL questionnaire dimension, as well as the mean, SD, median, minimum, and maximum values. The most affected dimension was disclosure concerns, followed by financial concerns, and HIV acceptance. The dimension with the best score was medication concerns.

\section{Discussion}

In this study, there was a predominance of poorly educated pregnant women, with incomplete elementary education. This is consistent with previous studies conducted in the same city, one of which was performed only with women, pregnant or not, regardless of positive HIV serology, that showed that from the 1,537 women interviewed, $55 \%$ had incomplete elementary education. ${ }^{16}$ Another study, which included HIV + men and women, showed that out of the 625 participants, $70 \%$ had up to 8 years of education, ${ }^{17}$ demonstrating that this is a strong characteristic of this population. However, when compared with studies conducted in the cities of the states of Ceará, with 45 patients, ${ }^{18}$ and São Paulo, with 85 patients, in which men and women with positive HIV serology participated, complete high school education was predominant. These authors highlight that patients with higher education may have better access to information about HIV infections and, therefore, more resources to live with their serological condition.

Although the household income in this study was slightly higher than that observed in a socio-behavioral and healthcare access study ${ }^{19}$ in which less than half of the participants had a household income higher than the minimum wage, it was noted that the pregnant women were still in a situation of financial hardship. In addition, regarding employment status, this study noted that a significant percentage of pregnant women are unemployed. Such status of low household income and unemployment make it difficult to live with HIV, negatively influencing their quality of life. A study that evaluated poverty aspects and HIV ${ }^{20}$ highlighted that gender inequalities, which also relate to poverty, put women in a significantly vulnerable situation for HIV infection. 
Table 3 Dimension scores of the HAT-QoL questionnaire from pregnant women with positive HIV serology $(n=27)$

\begin{tabular}{|l|l|l|l|l|l|l|}
\hline Dimension & $\mathbf{n}$ & Mean & SD & Minimum & Median & Maximum \\
\hline Overall function & 27 & 65.0 & 20.3 & 8.3 & 66.7 & 100.0 \\
\hline Satisfaction with life & 27 & 63.4 & 25.5 & 13.0 & 68.8 & 100.0 \\
\hline Health concerns & 27 & 62.3 & 31.5 & 0.0 & 75.0 & 100.0 \\
\hline Financial concerns & 27 & 49.1 & 36 & 0.0 & 50.0 & 100.0 \\
\hline Medication concerns & 19 & 80.8 & 26.5 & 5.0 & 95.0 & 100.0 \\
\hline HIV acceptance & 27 & 49.1 & 35.8 & 0.0 & 50.0 & 100.0 \\
\hline Disclosure concerns & 27 & 39.8 & 27.1 & 0.0 & 35.0 & 100.0 \\
\hline Provider trust & 27 & 70.7 & 25.2 & 0.0 & 75.0 & 100.0 \\
\hline Sexual function & 27 & $63 ., 8$ & 31.4 & 0.0 & 62.5 & 100.0 \\
\hline
\end{tabular}

Abbreviations: HAT-QoL, HIV/Aids Target Quality of Life; n, number; SD, standard deviation.

Note:* 23 reported having been prescribed antiretrovirals and 8 did not respond to this dimension.

The majority of pregnant women were contaminated with HIV through sexual intercourse, which may be related to poor knowledge about the use of condoms, since less than half of them answered correctly when asked about their use. Moreover, it is possible to relate this data to the patient's trust in her partner, as observed in a study conducted with women from some slums in São Paulo ${ }^{21}$ who believed that they maintained an exclusive relationship with their partners, in whom they trusted, and hence did not consider not using a condom as an unsafe sexual behavior.

It is important to highlight that the lack of knowledge about the use of condoms is alarming, since there are many campaigns promoting awareness about their proper use and advantages. Furthermore, many studies point to the opposite when it comes to HIV knowledge, as demonstrated by Ferreira (2008) ${ }^{22}$ in two periods, 1998 and 2005, when it was identified that the population's level of information regarding condom use increased - the percentage of people that were well informed went from $69.2 \%$ to $90.2 \%$.

Regarding the use of antiretrovirals for vertical transmission prophylaxis, a minority reported not having been prescribed these medications, despite their medical records indicating otherwise. According to the Ministry of Health $^{23}$, all HIV+ pregnant women must use antiretrovirals during pregnancy, labor and delivery, to reduce the chances of VT. A study that evaluated the expectations and actions of HIV+ pregnant women identified motivations that helped their adherence to medications, with the main ones being the fear of transmitting the virus to the baby and the fear of not being healthy enough to play the role of mother. ${ }^{24}$

Viral load and CD4 count are the most important biological markers of antiretroviral treatment success, and the lower the viral load of the mother, the lower the possibility of vertical transmission. The clinical profile, viral load and CD4 count described in this study are consistent with the values desired for people undergoing antiretroviral treatment, since, according to the Brazilian Ministry of Health guidelines, ${ }^{25}$ the objective of prophylaxis with antiretroviral medications is that the pregnant woman reach the labor and delivery time with the lowest viral load possible, preferably undetectable or at least lower than 1000 copies/ml.

Regarding the quality of life evaluation, medication concerns and provider trust were the dimensions that had the best scores in this study. An analysis to identify elements that influence quality of life in people with HIV $^{26}$ indicated that the use of antiretrovirals for AIDS treatment brings challenges that people need to know how to handle in order to achieve a healthier life. On the one hand, there is an increase in life expectancy and living with the side effects of medications; on the other, there is the necessity of daily life adjustments for the administration of these medications. The authors also suggest that receiving a diagnosis of positive HIV serology generates changes in the patient's life perspective; however, patients adapt themselves and learn how to live with the disease. Trust in the provider may be associated with the physician's empathy toward the HIV+ pregnant women's condition, which helps to create strategies that make adaptation to the disease easier. In a study that evaluated the adherence of HIV+ pregnant women to prenatal care, the group of pregnant women that came to the consultations reported the perception of feeling supported by the healthcare team, having a solid doctor-patient relationship, and that the team was interested in their wellbeing, highlighting the fact that they were treated without discrimination. ${ }^{19}$

Disclosure concerns were the most affected dimension, which leads us to think about the discrimination that these patients have to deal with and the stigmas that affect HIV+ individuals, which lead to constant negative impacts in their quality of life. In a study that described the social repercussions regarding AIDS in patients undergoing outpatient treatment in the public health system, which included men and women, individuals that lived with HIV have chosen to hide the disease to avoid discrimination and accusations, whether in their family, social, or work environments. Regarding the work environment, keeping their HIV status secret is a way of keeping their jobs, because if their positive serology is revealed, there is a risk of discrimination against those individuals. ${ }^{27}$ 
Another dimension that deserves to be highlighted is financial concerns. This dimension was also low in a study conducted with HIV+ pregnant women ${ }^{28}$, and in two other studies that included HIV+ men and women over 50 years old $^{29,30}$, all of which used the HAT-QoL instrument. All of them reinforced the importance that income has in quality of life, especially in people living with HIV-AIDS. Thus, these findings may be related to the low income of the individuals affected by the disease. Furthermore, their limited health and functional status may hinder their ability to obtain paid work and their inclusion in the job market, which leads us to the conclusion that quality of life is highly related to socioeconomic status and social exclusion. ${ }^{2}$ Thus, low income and unemployment may explain the low scores found for this dimension.

Regarding HIV acceptance, the pregnant women expressed regrets about their previous way of life and HIV exposure. Discovering a diagnosis of positive HIV serology is a traumatic experience that can cause psychological distress, mainly due to the fears of death, stigmatization, and discrimination. ${ }^{31}$ Considering the drama that the pregnant women still live with due to their positive HIV status and the fact that they live with the possibility of transmitting the virus to their offspring, which causes fear and insecurity, this score demonstrates the need for proper advice and follow up by healthcare professionals.

The main limitation of this study is the relatively low sample size, which makes it hard to perform an association analysis between the different quality of life instrument dimensions and the clinical and sociodemographic characteristics of the patients. The number of HIV+ pregnant women registered in the service is small, and every woman that had a consultation during the period of the study was included. The prevalence of pregnant women with positive HIV serology is low. Even with this limitation, this study brings important data about the quality of life of pregnant women with positive HIV serology that regularly use healthcare services, since literature data are still scarce on this subject.

It is possible that the pregnant women not included in this study due to their irregular attendance to consultations had lower rates of adherence, lower acceptance of their serological condition, lower connection with the healthcare service and, therefore, lower scores in all of the dimensions related to these conditions. Therefore, it is possible that the loss of such patients in this study influenced the results, biasing the scores upwards; thus, quality of life data may be overestimated. Therefore, we cannot extrapolate the results to all HIV+ pregnant women. Perhaps they can be extrapolated only for those that regularly attend prenatal care or have regular consultations in healthcare services.

Low adherence to prenatal care was observed in a qualitative study that evaluated the prenatal adherence of HIV+ women to the service. Out of the 40 patients interviewed by the study that measured access to the health system and prenatal adherence, 12 did not have any prenatal consultations, 20 had 1 to 5 , and 8 had 6 or more consultations. When evaluating the reasons behind the lack of prenatal adherence, the authors found that 34 pregnant women did not intend to get pregnant, 18 reported not having their partner's support, and 5 already knew they were HIV+ even before pregnancy, and reported that the prenatal services became worse. ${ }^{19}$ This study justifies our small sample size because, considering the fact that it is a convenience sample, the patients that came to the prenatal service were interviewed.

The findings of this study may contribute to improve knowledge about the subject and to establish interventions based on the needs of pregnant women that live with HIV, aiming to improve their quality of life, as well as support the improvement of healthcare assistance and monitoring, and help pregnant women in the fight against the disease.

\section{References}

1 Boletim Epidemiológico - Aids e DST [Internet]. 2015 [citado 2016 Fev 10];4(1). Disponível em: http://www.aids.gov.br/sites/default/ files/anexos/publicacao/2015/58534/boletim_aids_11_2015_web_ pdf_19105.pdf

2 Galvão MTG, Cerqueira ATAR, Marcondes-Machado J. Evaluation of quality of life among women with HIV/AIDS using HAT-QoL. Cad Saude Publica 2004;20(2):430-437

3 Samuel R, Bettiker R, Suh B. Antiretroviral therapy 2006: pharmacology, applications, and special situations. Arch Pharm Res 2006;29(6):431-458

4 Casado A. Measurement of quality of life of HIV individuals: Perspectives \& future directions. Indian J Med Res 2005;122(4): 282-284

5 Carr AJ, Higginson IJ. Are quality of life measures patient centred? BMJ 2001;322(7298):1357-1360

6 Herrmann S, McKinnon E, Hyland NB, et al. HIV-related stigma and physical symptoms have a persistent influence on healthrelated quality of life in Australians with HIV infection. Health Qual Life Outcomes 2013;11:56

7 Neves LA, Gir E. HIV positive mothers' beliefs about mothertochild transmission. Rev Lat Am Enfermagem 2006;14(5):781-788

8 Brasil. Ministério da Saúde. Secretaria de Vigilância em Saúde. Programa Nacional de DST e Aids [Internet]. Recomendações para profilaxia da transmissão vertical do HIV e terapia antirretroviral em gestantes: manual de bolso. Brasília (DF): Ministério da Saúde; 2010 [citado 2015 Abr 7]. Disponível em: http://www. aids.gov.br/sites/default/files/consenso_gestantes_2010_vf.pdf

9 Hodgson I, Plummer ML, Konopka SN, et al. A systematic review of individual and contextual factors affecting ART initiation, adherence, and retention for HIV-infected pregnant and postpartum women. PLoS ONE 2014;9(11):e111421

10 Reis RK, Santos CB, Dantas RAS, Gir E. Qualidade de vida, aspectos sociodemográficos e de sexualidade de pessoas vivendo com HIV/ AIDS. Texto Contexto Enferm. 2011;20(3):565-575

11 Costa FM, Souza IC, Ribeiro ZS, Santos JAD, Carneiro JA. Mulheres vivendo com HIV/AIDS: avaliação da qualidade de vida. Rev Saúde Pesqui. 2014;7(3):503-513

12 de Soárez PC, Castelo A, Abrão P, Holmes WC, Ciconelli RM. Brazilian-Portuguese translation and validation of the HIV/ AIDS-Targeted Quality of Life Instrument. Rev Panam Salud Publica 2009;25(1):69-76

13 Silveira MPT, Maurer P, Guttier MC, Moreira LB. Factors associated with therapeutic success in HIV-positive individuals in southern Brazil. J Clin Pharm Ther 2015;40(2):192-195

14 Silveira MPT, Pinheiro CAT, Guttier MC, Pereira TVS, Moreira LB. Description of pharmaceutical care to assess their effectiveness on adherence to antiretroviral therapy. A randomized clinical trial. J Med Med Sci. 2010;1(5):171-177 
15 Holmes WC, Shea JA. Performance of a new, HIV/AIDS-targeted quality of life (HAT-QoL) instrument in asymptomatic seropositive individuals. Qual Life Res 1997;6(6):561-571

16 Silveira MF, Béria JU, Horta BL, Tomasi E. Self-assessment of STD/ AIDS vulnerability among women, Brazil. Rev Saude Publica 2002; 36(6):670-677

17 Passos SM, Souza LD. An evaluation of quality of life and its determinants among people living with HIV/AIDS from Southern Brazil. Cad Saude Publica 2015;31(4):800-814

18 Galvão MTG, Soares LL, Pedrosa SC, Fiuza MLT, Lemos LA. Qualidade de vida e adesão à medicação antirretroviral em pessoas com HIV. Acta Paul Enferm. 2015;28(1):48-53

19 Darmont MdeQ, Martins HS, Calvet GA, Deslandes SF, Menezes JA. Adherence to prenatal care by HIV-positive women who failed to receive prophylaxis for mother-to-child transmission: social and behavioral factors and healthcare access issues. Cad Saude Publica 2010;26(9):1788-1796

20 Parker R, Camargo Junior KR. Pobreza e HIV/AIDS: aspectos antropológicos e sociológicos. Cad Saude Publica 2000;16 (Suppl 1):S89-S102

21 Praça NdeS, Gualda DMR. Risk of HIV infection: how women living in a slum perceive themselves in the chain of the virus transmission. Rev Lat Am Enfermagem 2003;11(1):14-20

22 Ferreira MP; Grupo de Estudos em População, Sexualidade e Aids. Knowledge and risk perception on HIV/AIDS by Brazilian population, 1998 and 2005. Rev Saude Publica 2008;42 (Suppl 1):65-71

23 Brasil. Ministério da Saúde. Departamento de DST, Aids e Hepatites Virais [Internet]. AIDS no Brasil. Brasília (DF): Ministério da Saúde; 2012 [citado 2015 Abr 7]. Disponível em: http://www. aids.gov.br/pagina/aids-no-brasil
24 de Moura EL, Praça NdeS. HIV perinatal transmission: expectations and actions of HIV-positive pregnant women. Rev Lat Am Enfermagem 2006;14(3):405-413

25 Brasil. Ministério da Saúde. Secretaria de Vigilância em Saúde. Coordenação Nacional de DST/AIDS [Internet]. Recomendações para a profilaxia da transmissão materno-infantil do HIV e terapia anti-retroviral em gestantes. Brasília (DF): Ministério da Saúde; 2007 [citado 2015 Abr 7]. Disponível em: http://bvsms.saude.gov. br/bvs/publicacoes/recomendacoes_profilaxia_hiv_antiretroviral_gestantes.pdf

26 Meirelles BHS, Silva DMGV, Vieira FMA, Souza SS, Coelho IZ, Batista R. Percepções da qualidade de vida de pessoas com HIV/ AIDS. Rev Rene. 2010;11(3):68-76

27 Gomes AMT, Silva EMP, Oliveira DC. Representações sociais da AIDS para pessoas que vivem com HIV e suas interfaces cotidianas. Rev Lat Am Enfermagem 2011;19(3):485-492

28 Tirado MdoC, Bortoletti FF, Nakamura MU, et al. [Quality of life of pregnant women infected with the human immunodeficiency virus (HIV) in the city of São Paulo]. Rev Bras Ginecol Obstet 2014; 36(5):228-232 Portuguese

29 Lopes PSD, Silva MMG, Torres IC, Stadñik CMB. Qualidade de vida dos pacientes HIV positivo com mais de 50 anos. Rev AMRIGS. 2011;55(4):356-360

30 Okuno MF, Gosuen GC, Campanharo CR, Fram DS, Batista RE, Belasco AG. Quality of life, socioeconomic profile, knowledge and attitude toward sexuality from the perspectives of individuals living with Human Immunodeficiency Virus. Rev Lat Am Enfermagem 2015;23(2):192-199

31 Oliveira ADF, Vieira MCA, Silva SPC, Mistura C, Jacobi CS, Lira MOSC. Repercussões do HIV no cotidiano de mulheres vivendo com AIDS. J Res Fundam Care Online 2015;7(1):1975-1986 